\title{
1. Typologies of corruption: a pragmatic approach
}

\section{Jennifer Bussell ${ }^{1}$}

Studies of corruption provide much evidence on both the causes and consequences of corruption, and yet progress remains strikingly limited on the conditions under which these causes may be relevant and these consequences occur. If an anti-corruption reform successfully attenuates corruption in one context, should we expect the same to occur elsewhere? What information do we need about both the intervention and the nature of the corruption itself to answer this question?

The goals of this chapter are threefold: first, to highlight issues of conceptualization and measurement in the existing literature on corruption that limit our ability to cumulate knowledge about corruption's causes, effects, and the potential for reform. Second, to argue for a more explicit but pragmatic approach to typologies of corruption that should improve our ability to cumulate knowledge while not limiting the analytic endeavor. And, third, to present a new typology of corruption that is intended to facilitate analyses specifically aimed at identifying those individuals with a vested interest in existing forms of corruption.

I suggest that within a basic definition of corruption, there are many ways in which we can distinguish between different types of corrupt behavior. Each typology may be useful for a particular purpose. None may be useful for all purposes. Thus, it is essential to our analytical endeavors first, to acknowledge the diversity of ways in which we discuss and analyze corruption and, second, to be clear in each analysis about the form of corruption under investigation and why we are conceptualizing and measuring it in a particular manner. An important element of this is to recognize that we may work within a single typological tradition, such as that distinguishing between petty and grand corruption, while

1 I would like to thank participants at the Conference on Grand and Petty Corruption in Developing States at Yale University for comments on an earlier draft. 
only addressing a certain type of corruption in our analysis, such as petty corruption.

Using a range of examples from the rich literature on corruption, I highlight the lack of attention to these issues in most current research and the resulting difficulties related to cumulating knowledge on the nature of corruption. I then consider existing typologies of corruption and, drawing on the democratization literature, argue that a diversity of typologies, rather than one primary typology, may be most analytically useful. I subsequently present a new typology based on the nature of state resources and highlight how this framework offers leverage for distinguishing the types of actors involved in different forms of corruption.

\section{FRAMEWORKS FOR CONCEPTUALIZING CORRUPTION}

To a certain extent, 'corruption' is a case in which there is relatively little empirical debate about what corruption 'is'. While considerable work has deliberated on the concept of corruption itself (see, inter alia, Philp 2002, Heywood 1997, Gardiner 2002 (1993), Alatas 1990, and Friedrich 2002 (1972)), there is little substantive debate about the definition of corruption in practice. Corruption is taken to be the abuse of public office for private gain (see, inter alia, Olken 2007, Bardhan 2006, Jain 2001, and Rose-Ackerman 1975) - a definition that has become the most commonly utilized characterization. Rarely do analysts allocate substantial, or even minimal, discussion to the justification of this specific conceptualization. ${ }^{2}$

I want to suggest that there should be substantially more debate, or at the very least discussion, about the concept of corruption. I am especially concerned with conceptualizing various types of corruption. The phrase 'the abuse of public office for private gain' offers little insight into how to distinguish between different forms of abuse; yet analyzing the diverse forms is often at the heart of analyses of corruption. Thus, we need a more comprehensive consideration of variation within the concept of corruption.

A number of analysts have offered more specific typologies of corrupt behavior. One framework, posed by Kaushik Basu, differentiates between

2 This is perhaps because this definition seems relatively straightforward and offers a concise starting point for categorizing various behaviors as corrupt or not. However, I set aside here a detailed analysis of why this particular conceptualization has taken root. 
'harassment' bribes, those 'that people often have to give to get what they are legally entitled to', (Basu 2011:3) and 'non-harassment' bribes, which are those 'that are believed to occur when government gives out big development contracts' (Basu 2011: 8). This is similar to Alatas' description of 'transactive' versus 'extortive' corruption, in which 'The former refers to a mutual arrangement between a donor and a recipient, actively pursued by, and to the mutual advantage of, both parties, whereas the latter entails some form of compulsion, usually to avoid some form of harm being inflicted on the donor or those close to him/her' (Heywood 1997: 425-6). The distinction is a powerful one, because it distinguishes between bribe givers who rightfully deserve whatever they receive as a result of the bribe and those who would not deserve the object/service/contract under question regardless of the bribe. Thus, the underlying incentives and legal rights of those involved in the two types of bribes may be quite different.

A more commonly utilized distinction, highlighted by Rose-Ackerman (1999), is between petty and grand corruption. The former refers to bribes citizens pay to lower-level officials either to speed the delivery of services or to bribe officials to 'bend the rules' (Rose-Ackerman 2002; Cisar 2003), while the latter 'involves large sums of money with multinational corporations frequently making the payoffs' and politicians using their power to shape policies in ways that benefit bribers (Rose-Ackerman 2002; Jain 2001; see also Bussell 2012). A related distinction is sometimes made between retail and wholesale corruption, with retail corruption described as 'millions of small transactions where people go to get a service and have to pay some ... rent ... for consummating that transaction' (Nilekani 2013), while 'wholesale corruption happens at a macro scale ... in land, spectrum, or natural resources' (ibid.).

Heywood notes that, beyond these initial two, a multitude of typologies is possible:

distinctions could be drawn between ... the local and national level (the former being site of widespread corruption in regard, for instance, to municipal public works contracts); between personal and institutional corruption (that is, between corruption aimed at personal enrichment and that which seeks to benefit an institution such as a political party); between traditional and modern forms of corruption (for instance, nepotism and patronage versus money laundering through electronic means); and so forth (Heywood 1997: 426).

Thus, the literature and public discourse are rich with typologies, or potential typologies, of corruption, and yet there is little consideration of whether a particular typology should be used or when it should be used. I posit that this lack of deliberation is a problem. If we are serious about understanding the dynamics of corruption both theoretically and 
empirically, then a more meaningful conversation about the ways in which we operationalize the concept is necessary for pushing forward our knowledge.

Attention to typologies in work on corruption is particularly important due to limitations in the ways in which typologies are currently used, both generally and with regard to specific analytical tasks. First, the empirical literature, in practice, largely ignores variation in corruption, typically analyzing only one example of corrupt behavior without categorizing it as a particular form of corruption. This imprecise link between concept and measurement is highlighted in a review of classic and more recent works on corruption shown in Table 1.1. For each article or book, I note the definition of corruption used, if given, and the measurement technique of the analysis, as well as the associated independent or dependent variable(s). Although there is often a reasonably logical match between the measure of corruption and the independent or dependent variables under consideration, there is typically no definition of corruption provided, let alone a specification of the type of corruption that would allow us to compare results across individual analyses. Of the 26 pieces included in the review, only eleven (42 percent) explicitly state the definition of corruption with which they are working. Only three (11.5 percent) pieces, one of which is a review article and one of which is written by the author of this chapter, acknowledge the potential for different types of corruption and address these types in their discussion.

Hence, analyses of corruption are problematic for the purposes of cumulating knowledge on at least two levels. First, it is difficult to tell if analysts are using the same initial concept of corruption to inform their theoretical perspective. This makes it largely, if not entirely, impossible to determine whether the corruption considered in one analysis 'should' be the same or different from that evaluated elsewhere. Second, even in those cases where analysts specify their concept of corruption, the operationalization of that concept is likely to differ dramatically across empirical analyses. As Kramon and Posner note, 'some researchers measure [corruption] in terms of local bribe taking by civil servants; others in terms of the valuation of publicly traded companies with connections to top government officials; others in terms of tax evasion; and others in terms of leakage in public expenditure' (Kramon and Posner 2013: 469). These differences in measurement strategies may simply reflect the difficulty of collecting data on corruption, but this does not change the fact that any effort to compare across analyses will be stymied by differences in measurement. Such measurement issues may also result in a set of analyses with quite different findings regarding what factors encourage corrupt behavior and how corruption affects political and social outcomes. 


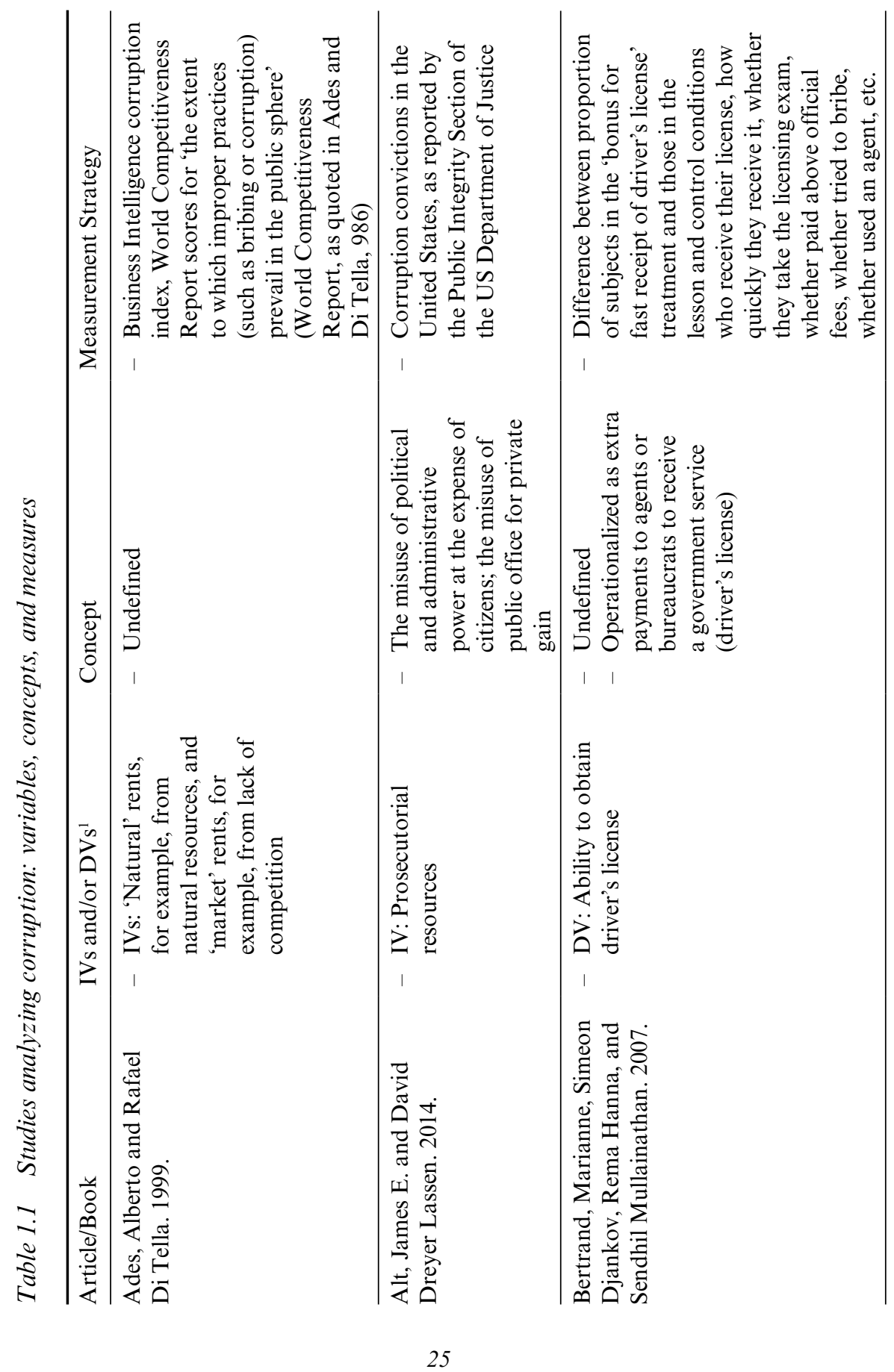




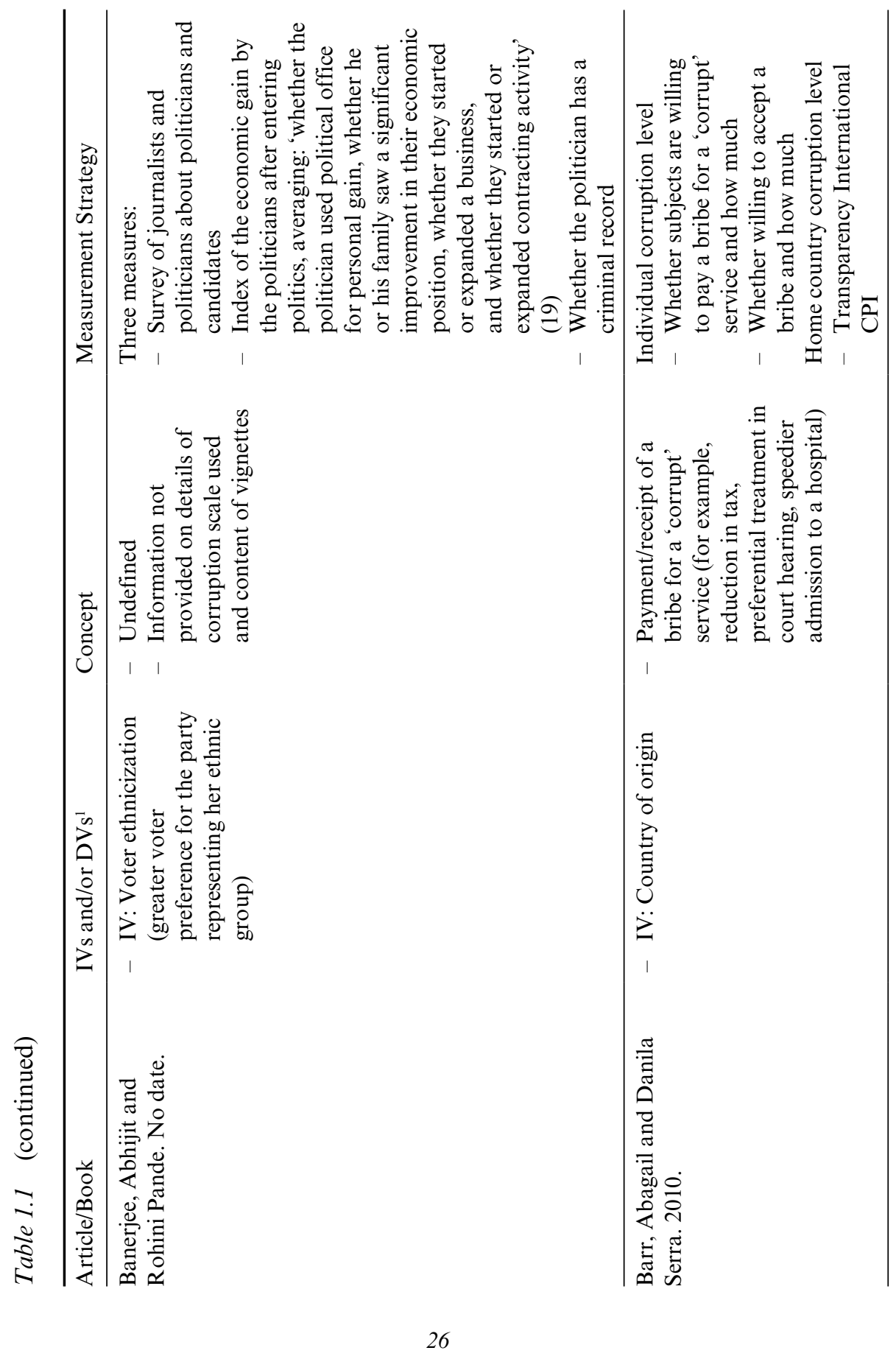




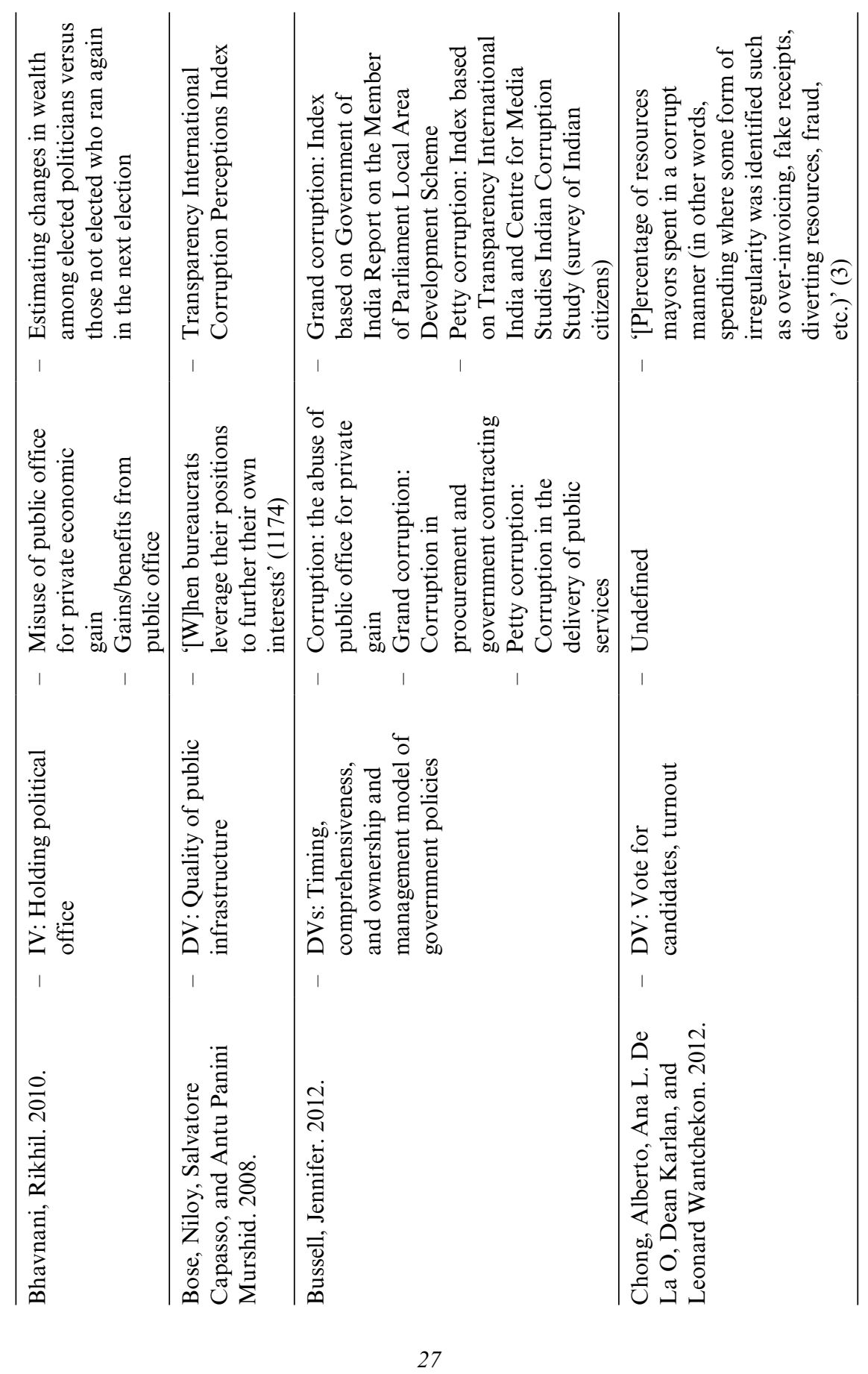




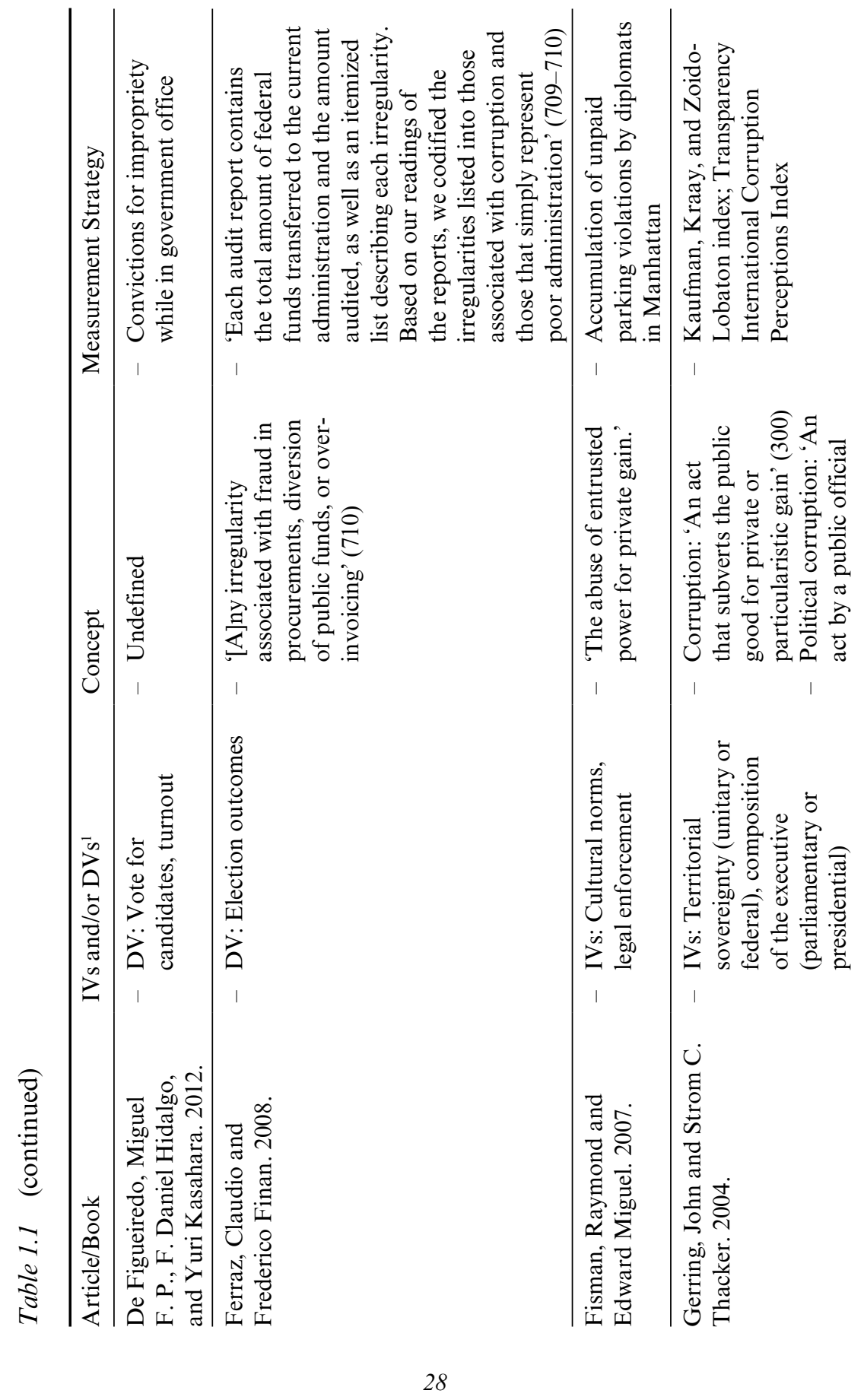




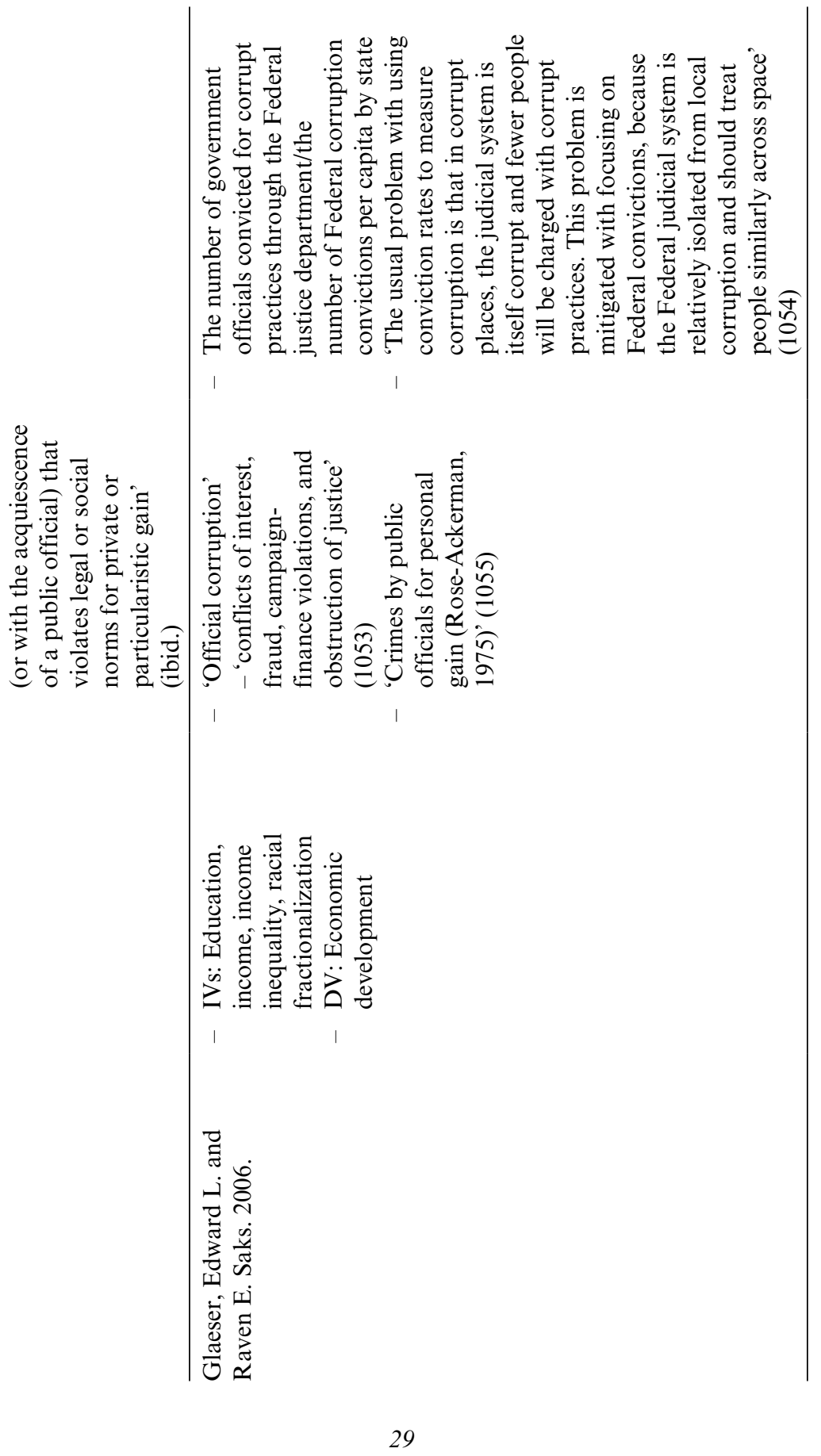




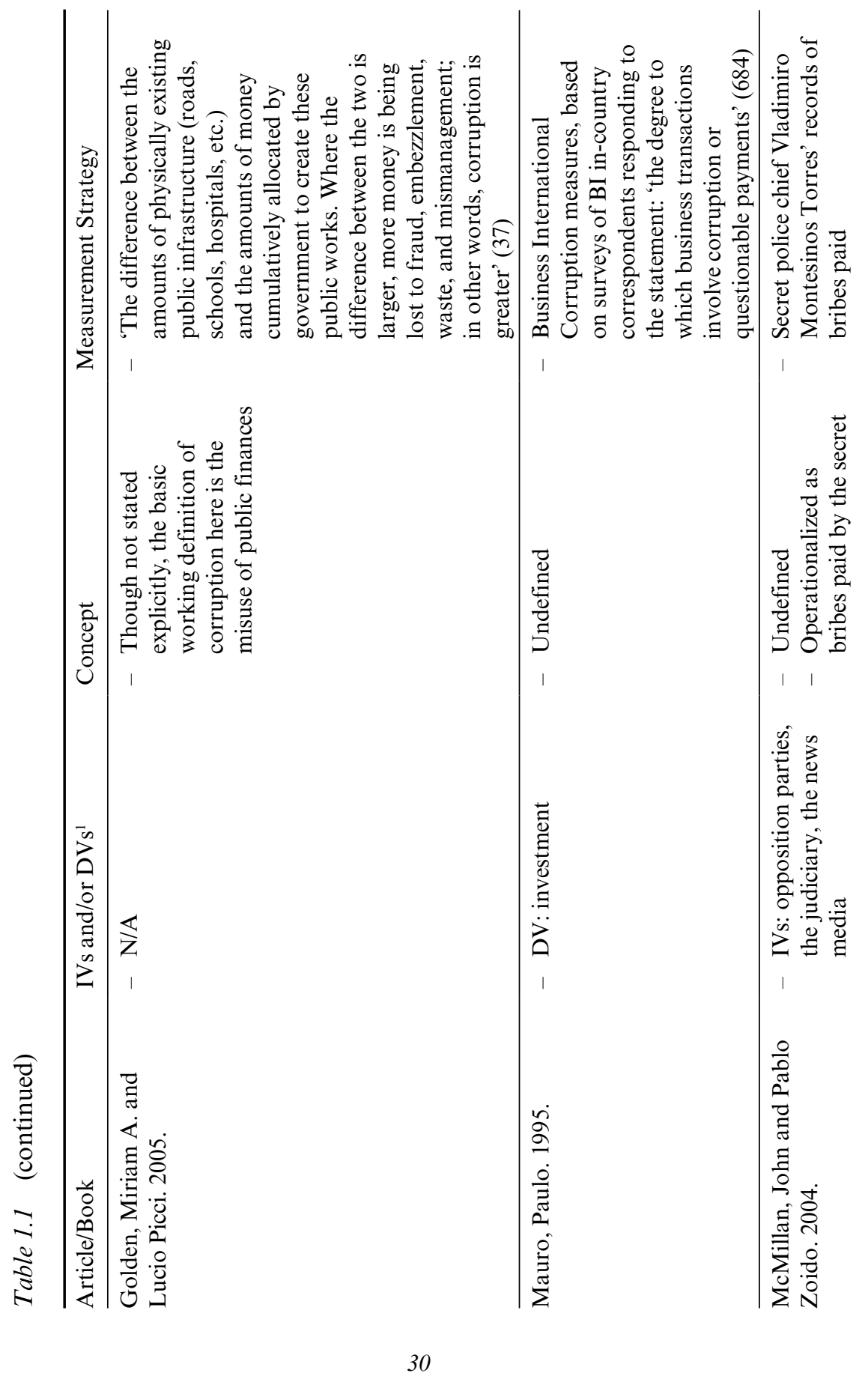




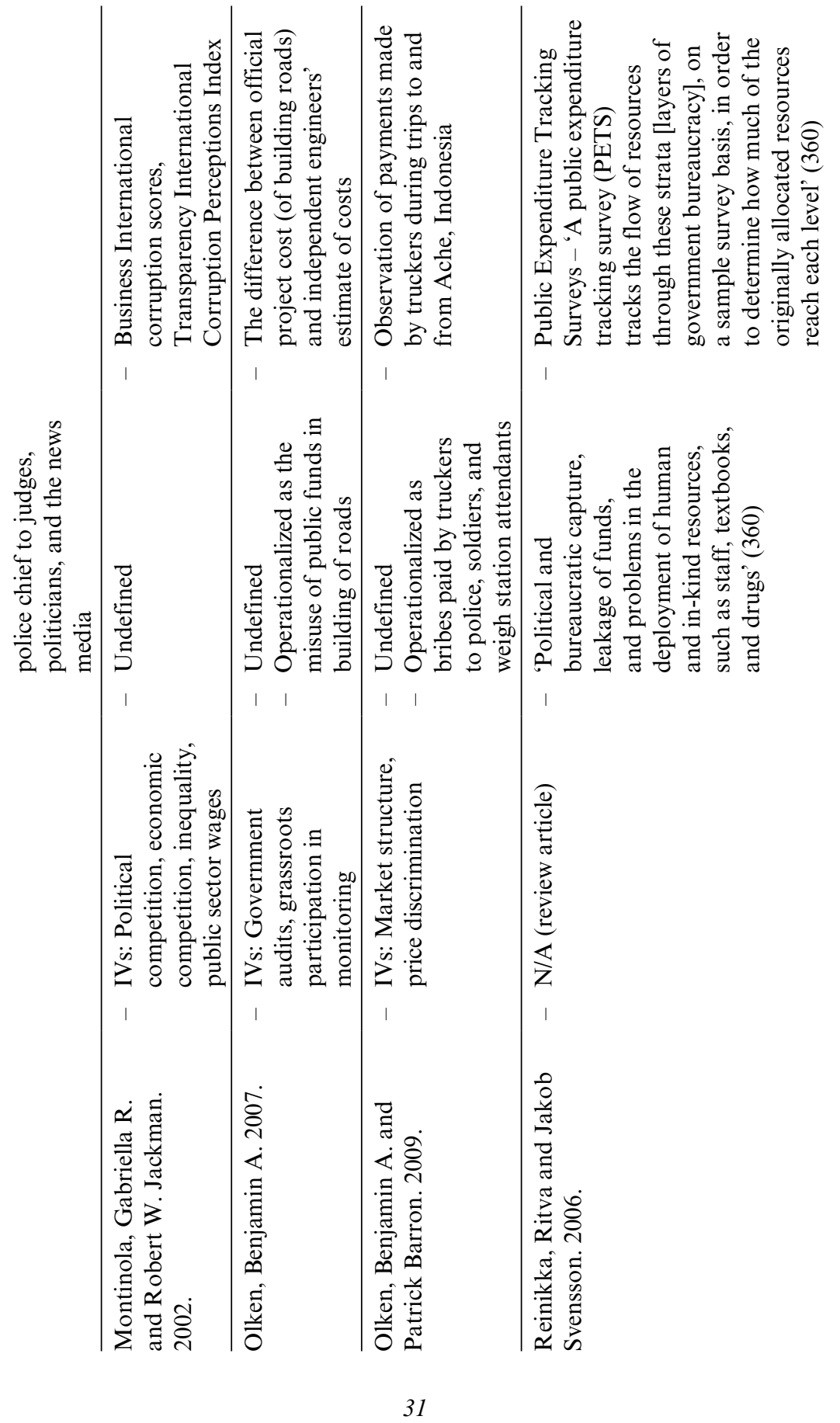




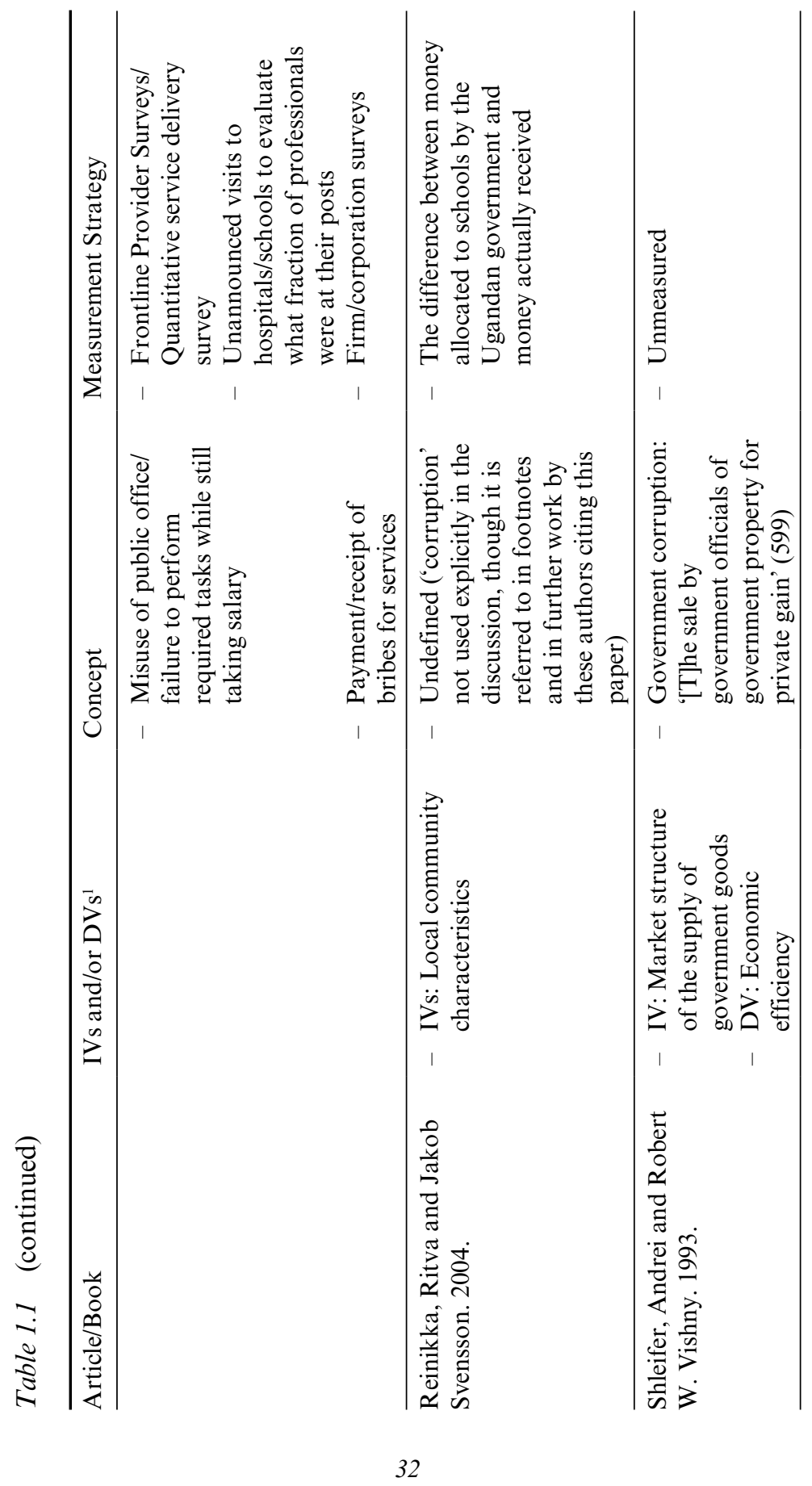




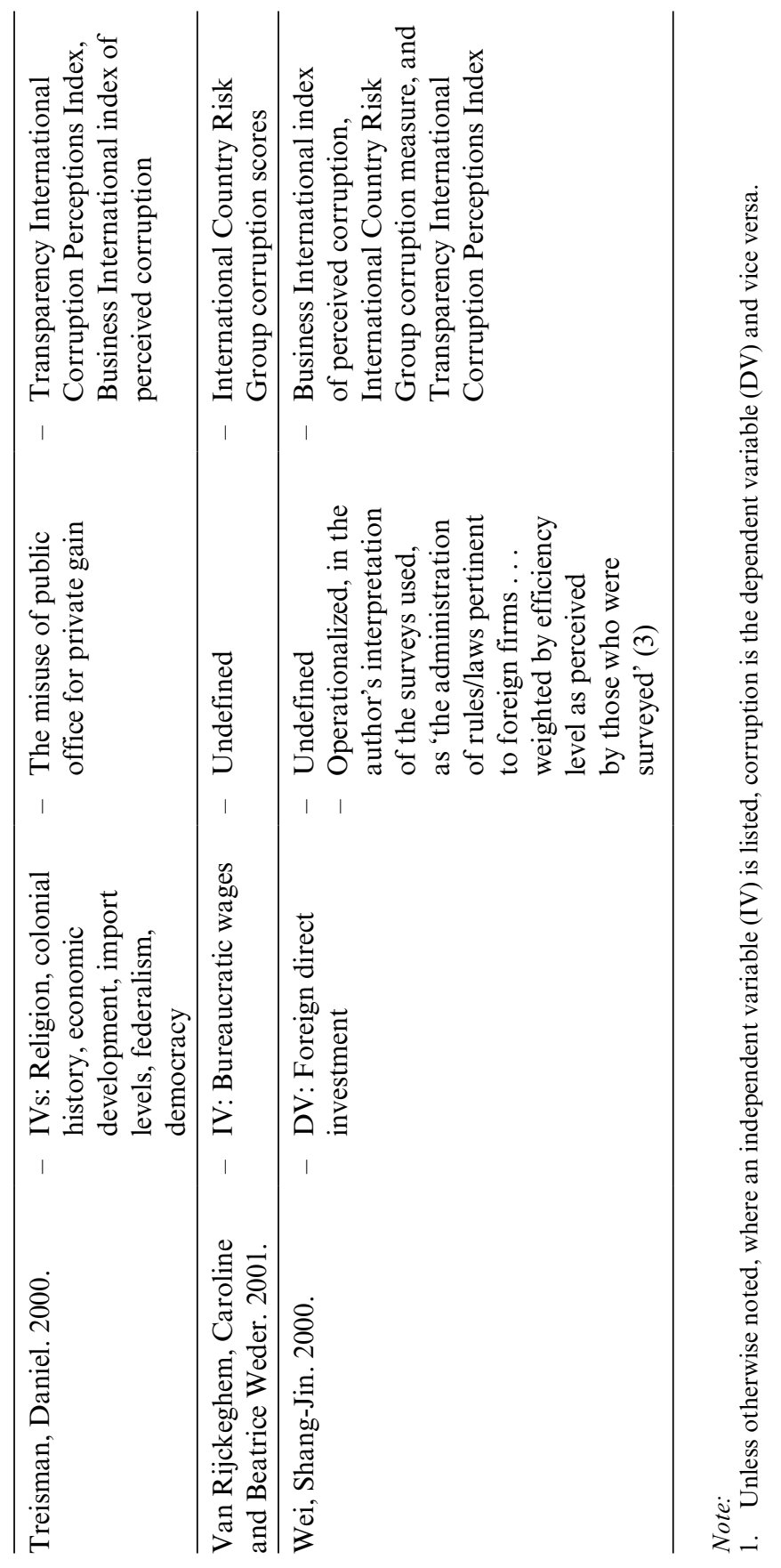


A second limitation is that existing typologies are often insufficient for the range of potential analyses on this topic. Take, as an example, the common distinction between petty and grand corruption. Although this dichotomy can be quite useful in distinguishing between the type of corruption frequently faced by individual citizens in developing countries and the type of corruption engaged in by high-level officials around the world, it is insufficient for addressing, conceptually, certain other forms of corruption. For instance, in their analysis of municipal-level corruption in Brazil, Ferraz and Finan highlight that 'most corruption schemes used by local politicians to appropriate resources are based on a combination of fraud in procurements, the use of fake receipts or 'phantom' firms, and over-invoicing the value of products or services' (Ferraz and Finan 2008: 710). This corruption in contracting over government resources is quite common in developing countries but does not necessarily fit the characteristics of grand and petty corruption just discussed. Thus, if one is interested in analyzing contracting corruption engaged in by relatively low-level political and bureaucratic actors, the petty versus grand typology seems insufficient.

Similarly, consider the alternate distinction posed above between harassment and non-harassment bribes. Although this typology is arguably more comprehensive than the distinction between petty and grand corruption, it is too broad for certain types of analysis. For example, take two examples of non-harassment bribes. In one case, a traffic officer and a driver who has been speeding agree on a direct payment to the officer rather than a speeding ticket. In another case, a politician receives a kickback for shepherding particular industrial regulations through the political process. The actors in these two transactions are both engaging in non-harassment bribe-taking, yet they operate at different levels of government and under different authority structures.

Given the limitations of existing typologies, how should we think about appropriate strategies for typological alternatives and conditions under which one typology may or may not be appropriate? In the next section, I draw on debates in the literature on democracy to suggest a pragmatic model for analyzing corruption in its various forms.

\section{FROM GRADATIONS OF DEMOCRACY TO TYPES OF CORRUPTION}

The literature on democracies and non-democratic regimes offers a useful example of a field in which, some argue, settling on a single definition and measurement strategy is less useful than allowing multiple approaches to 
thrive, depending on the analytic goal. In their discussion of debates on whether a dichotomous or graded measure of democracy is more appropriate, Collier and Adcock argue that 'This recurring and much debated question has important implications for how research is organized, for how data are collected and analyzed, and for inferences about the causes and consequences of democracy' (Collier and Adcock 1999: 537-8). In doing so, they highlight examples of analyses, such as those investigating the relationship between regime type and political stability (Elkins 1999), where different measurement strategies produce strikingly different findings (Collier and Adcock 1999: 538-9).

While scholars of democracy often express strong opinions about dichotomous versus graded measures, Collier and Adcock, instead of reflecting one side in this debate, argue that 'specific methodological choices are often best understood and justified in light of the theoretical framework, analytic goals, and context of research involved in any particular study' (Collier and Adcock 1999: 539). In other words, 'how scholars understand and operationalize a concept can and should depend in part on what they are going to do with it' (ibid.).

I suggest that this perspective is directly relevant to the literature on corruption. Where Collier and Adcock are responding to a debate over the appropriate measurement of democracy, be it graded or dichotomous, greater attention to the ways in which we distinguish between corrupt behaviors, or typologies of corruption, within a given general conceptualization, also offers important analytic opportunities. Concepts and typologies are useful for a great number of scholarly purposes, but they are particularly important for distinguishing what exactly is the topic under consideration and differentiating, within that topic, between different manifestations. Rather than attempting to fit one typological schema onto all efforts to analyze corruption, we are better served by explicitly identifying the character of corruption that is relevant to our analytic goals and then working within that conceptual definition and, if necessary, suitable typology.

What, then, is an appropriate strategy for thinking about what the most useful typology of corruption would be in a given analysis? Returning again to the literature on democracy, Collier and Adcock note that there may be multiple ways in which the theoretical and empirical goals of a particular piece of research can inform choices about concepts and measurement in general and the use of typologies in particular (Collier and Adcock 1999: 550). The choice of conceptual approach may be guided inductively by the empirical distribution of cases, it may be structured by a normative concern, or it may instead be informed by a theoretical hypothesis about the topic at hand (Collier and Adcock 1999). For example, one reason 
many analysts seem to use a dichotomous approach to democracy and non-democracy is the empirical context. Historically, country cases have tended to cluster in two groups, one with more democratic features and the other with more nondemocratic features (Collier and Adcock 1999: 554-5). Analysts saw this grouping itself as an important characteristic in the transition to democracy and so focused on a dichotomous measure (ibid.). Alternatively, O'Donnell and Schmitter (1986) adopted a normative standard for democracy, a 'procedural minimum' that would establish a target for transitional states and, in doing so, lead to a clear distinction between those states that do and do not meet these standards (Collier and Adcock 1999: 556-7). Finally, theoretical concerns may inform the use of a particular typological strategy, as was the case for O'Donnell's (1994) work on delegative democracies, which focused on a sub-type of democracy as an independent variable. In this case, he argued that a feature of specific democracies, 'regimes with strong presidencies in which the 'horizontal accountability' of the executive to the legislature is attenuated' (Collier and Adcock 1999: 553) had particular effects on political institutionalization.

Each of these perspectives may be relevant to analyses of corruption. Empirically, the distinction between petty and grand corruption, though limited in the ways I suggest above, seems to have been driven by a sorting of observed corrupt behaviors into those experienced by every-day citizens and those engaged in by high-level politicians and private companies 'behind the scenes'. Normatively, a simple dichotomous measure of corruption or its absence may be most relevant for distinguishing the effects of corruption on policy outcomes. For instance, do corrupt political leaders lead to lower growth rates? In order to answer this question, it might be most helpful to count the number of corrupt or honest politicians holding office, rather than to measure gradations of corruption among office holders. Theoretically, we might expect different kinds of corruption to be related to different types of policy outcomes. In my work on administrative reforms in India, I distinguish between petty and grand corruption because I hypothesized that petty corruption would have different effects on policy choices related to government technology adoption than would grand corruption (Bussell 2012). As a result, it was important both to differentiate between these forms of corruption conceptually and to measure them differently in the empirical analysis.

The implication of these different logics of conceptualization and measurement is that there is no one right strategy and, instead, there are different reasons for choosing different typological strategies. What is important is that one is explicit about one's strategy and, where possible, clear on the logic for choosing it for a particular analysis. In the next 
section, I provide an example of, and the logic for, a new typology that was developed specifically to address an analytic question where existing typologies seemed insufficient.

\section{STATE RESOURCES AND TYPES OF CORRUPTION}

Many corruption analyses seek to understand the underlying dynamics of corrupt transactions so as to facilitate anti-corruption reforms. In particular, we are often interested in the incentives of actors engaged in corrupt activities, so as to design anti-corruption interventions that target the underlying causes of these behaviors. Yet, these efforts tend only to consider the actors involved in a very general way-for example, civil servants or elected officials - which may be insufficiently specific for identifying the relevant incentives at play.

One strategy for distinguishing between individuals with different corrupt incentives is to focus on corruption as it relates to different types of state resources, such as welfare benefits, natural resources, and public contracts. Considering who has control over these resources can help to focus attention on the relevant sets of individuals. This approach is theoretically driven: if different individuals control different state resources, then identifying variations in corruption related to those resources should help us to understand how the incentives to engage in corruption differ across individuals. If one wants to understand who is benefitting from a particular form of corruption, such as bribes taken in the delivery of basic services, it is necessary to identify who has power over these resources.

The nature of control over state resources has previously been highlighted as an important factor shaping the nature of corruption. Shliefer and Vishny (1993) argue that two features of institutional structures, government centralization and bureaucratic competition, play primary roles in shaping opportunities to extract rents and so influence the prevalence and predictability of corruption in a given regime. Centralization makes corruption predictable because 'In such places it is always clear who needs to be bribed and by how much. The bribe is then divided between all the relevant government bureaucrats, who agree not to demand further bribes from the buyer of the package of government goods, such as permits' (Shleifer and Vishny 1993: 605). Competition between bureaucratic agents makes corruption less likely in general because individuals can go to an alternative provider if they are asked for a bribe (Rose-Ackerman 1978: 137-66).

Implicit in the discussion of centralization and competition is the 
understanding that these characteristics affect the incentives of agents who are responsible for distributing resources over which the state maintains control. These individuals can feasibly restrict access to state resources, such as welfare benefits or mining licenses, and so have the potential to extract bribes from individuals or organizations with an interest in the resources. Where power is centralized, agents of the state have little independence to determine their preferred level of rent extraction, and where there is competition, market forces exert downward pressures on rent-seeking.

Within these institutional constraints, however, the specific actor, or set of actors, with the potential to extract bribes will most likely depend on the type of state resource being distributed. Resources may be allocated either by elected officials or civil servants, with politicians, on one hand, typically overseeing resource allocation as they make policy, such as through pork barreling, or through direct spending in their region, as in constituency development funds. Bureaucrats, on the other hand, tend to allocate resources in the implementation of policy that is already in place, such as through negotiations over state contracts and the delivery of public services to particular individuals and firms. Within these two categories, there may be a wide range of individuals who have power over specific state resources, given their level of government and their positions within a particular department.

This spread of responsibility across actors is especially important in decentralized regimes, as noted by Shliefer and Vishny, because it increases the number of actors who may be able to act on their own to extract bribes from the public. More specifically, in a highly decentralized state there is likely to be substantially more variation in the power structures across government. This variation may affect patterns of corruption in at least two ways.

First, decentralization of authority implies that actors at different levels of government have control over different government resources. For example, a bureaucrat at the highest level of government may be in charge of implementing an auction to allocate licenses for land rights to build cross-country high-speed rail lines. A bureaucrat at a middle level of government may be charged with overseeing the building of health centers, while at the most local level, bureaucrats are likely to be responsible for delivery of resources such as welfare benefits and utility connections. Thus, we should observe differing actors benefiting from corrupt activities, depending on the type of resource and the level of government at which it is allocated.

Second, decentralization may also affect the range of actors who are able to benefit from the distribution of a single resource. For example, in the 
allocation of licenses to extract natural resources, a policy may be written by the central government legislature to structure licensing and then the license may be allocated to a large company by the central government, giving these bodies access to potential corrupt rents in these processes. At the sub-national level, however, the state or provincial government with control over the region in question may also play a role in giving approval to begin extraction in a specific location, and local governments may have the power to exert control over final access to the land. Thus, there may be multiple points at which different actors can extract rents related to a single resource.

The discussion to this point emphasizes only forms of formal control over the distribution of resources. However, there may be more informal ways in which actors who do not have direct control over a state resource can still extract rents from bribes paid for access to that resource. I characterize this kind of power over rent extraction as indirect influence and posit that it may arise from direct control over either individuals or over information. Where someone has power over another individual related to the latter's position within the state, the former individual may be able to leverage this power to extract rents from corruption in which the latter is engaged. Alternatively, if someone wants to engage in corruption but cannot do so without information provided by another individual, this latter individual may be able to use his or her power over information to collect some portion of any bribe payments.

I explore these dynamics in greater detail in the context of four types of state resources, which represent significant loci of corruption: policies (formal legislation and departmental regulations), public licenses and contracts, government jobs, and public goods and services. In each case, the specific individuals with direct control and indirect influence over a resource may differ across national contexts. I provide a generic discussion of one way in which these power dynamics could operate in a decentralized institutional environment.

With regard to policies, direct control typically sits with legislators, who shape the final content of legislation and with cabinet officials who issue departmental regulations. However, bureaucrats also often contribute to legislative content by participating in the drafting of bills and rules. External actors, such as lobbyists, may influence the content of policies through their relationships with politicians and top executive branch officials.

Public licenses and contracts, such as licenses allocating rights to natural resources and contracts to build public structures, may be shaped by legislation but determined in practice by procedures formally overseen by bureaucrats. At the same time, politicians may reassert their influence over 
these resources through indirect control over bureaucrats, such as with threats or promises related to transfers or promotions within government.

Control over the allocation of public sector jobs, however, is contingent on administrative guidelines related to merit-based procedures for hiring and promoting civil servants. Where merit-based procedures do not exist, patronage politics may instead determine the allocation of employment resources. These patronage relationships can then offer indirect influence over the distribution of resources, as previously noted.

Finally, civil servants also directly control the provision of goods and services to citizens. These individuals determine who receives benefits, among both the set of qualified individuals and those who do not meet eligibility criteria but still desire a specific good. Here, again, politicians who have influence over bureaucrats' jobs may be able informally to shape the allocation of these resources.

In any of these cases, middlemen may exert informal influence in the distribution of resources. This is most likely in situations where there is an opportunity to provide information and coordinate corruption because politicians or bureaucrats require private information, which can be accessed by the middleman, on which individuals are willing to pay an additional 'fee' to secure the resource.

This discussion highlights the ways in which paying attention to the particular resource can help to illuminate the specific actors with potentially entrenched interests in corruption. In each of these cases, the individuals with direct control and indirect influence over the allocation of the resource are those most likely to benefit from corruption. As a result, they are the individuals who are the most relevant for consideration in any effort to reduce corruption. Table 1.2 summarizes this discussion and provides a typological framework distinguishing between legislative, contracting, employment, and services corruption, using the type of government resource as a starting point for analyzing the actors involved in corrupt activities. ${ }^{3}$

\section{CONCLUSION}

Analysis of corruption is an inherently difficult task, due to its illicit nature. As a result, the accumulation of knowledge about corruption is a

3 As noted in the earlier discussion, the specific actors with power over a given resource may change across institutional settings and so must be revisited in the context of any given analysis. 


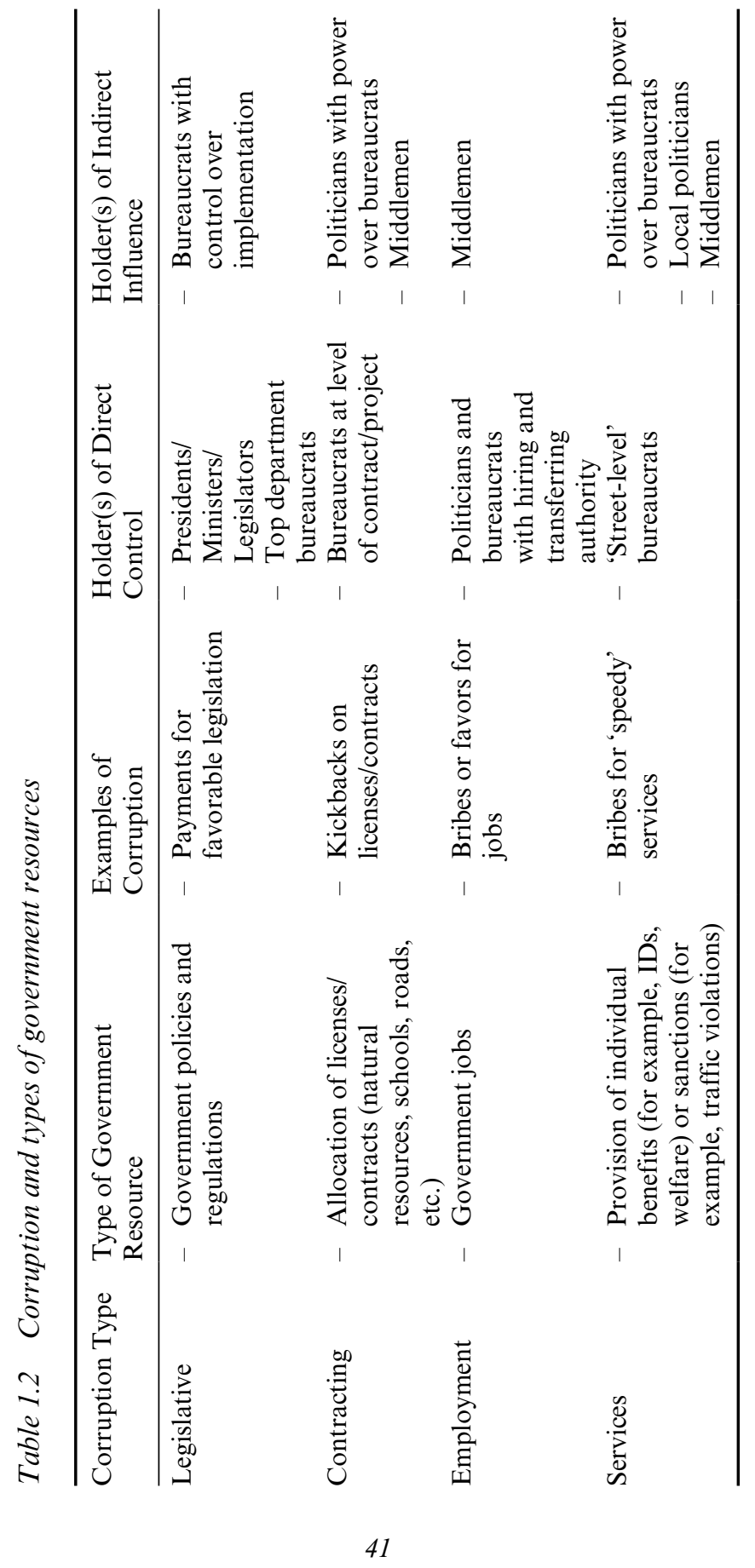


significant but problematic goal. In addition, our understanding of corruption has been stymied by inattention to the ways in which we conceptualize and measure the forms of corruption. I posit that this is a substantial, but surmountable, barrier to progress both in research on corruption and attempts to implement anti-corruption reforms.

In this chapter, I have highlighted how existing research conceptualizes or does not conceptualize corruption in practice with an emphasis on the limited and insufficient use of typologies to clarify the practice(s) being evaluated. Not only do analysts often not specify what they mean by 'corruption', they are even less likely to specify the type of corruption they study.

Rather than arguing for one single shared typology for use across all analyses, a strategy that would, in theory, promote more consistent, comparable analyses, I have argued for a more pragmatic, problem-driven approach. Given the complex nature of corruption, it is highly unlikely that a single typology will be sufficient for all research questions. Instead, we should strive to be transparent and clear about the model being used and the logic behind its adoption. In doing so, we can encourage the adoption of specific typologies for appropriate research programs, to be shared across analysts with interests in related questions, and thereby facilitate the building of knowledge within these specific domains.

In order to illustrate how this might be done, I first highlighted limitations in existing typologies. I then presented a new typology that I claim is useful for analyses where the researcher seeks to identify specific individuals who may be involved in corrupt activities. By disaggregating the types of state resources over which corruption may occur, I highlight different sets of actors who may have vested interests in corrupt practices. While the specific actors with power over a given type of resource will vary across institutional contexts, the general framework should provide useful guidelines for thinking about which actors are relevant to different forms of corruption. Alternative typologies, including existing distinctions between harassment and non-harassment bribes or petty and grand corruption, may be more relevant for other analytic tasks. What is most important is that we, as analysts, are clear about the strategy that we adopt, with the goal of increasing our ability to know what we have learned and what its policy implications might be.

\section{REFERENCES}

Ades, Alberto and Rafael Di Tella. 1999. 'Rents, Competition, and Corruption', The American Economic Review 89(4): 982-93. 
Alatas, Syed Hussein. 1990. Corruption: Its Nature, Causes and Functions. Aldershot, UK: Avebury.

Alt, James E. and David Dreyer Lassen. 2014. 'Enforcement and Public Corruption: Evidence from the American States', Journal of Law, Economics, and Organization 30(2): 306-38.

Banerjee, Abhijit and Rohini Pande. No date. 'Parochial Politics: Ethnic Preferences and Politician Corruption', working paper.

Bardhan, Pranab. 2006. 'The Economist's Approach to the Problem of Corruption', World Development 34(2): 341-48.

Barr, Abagail and Danila Serra. 2010. 'Corruption and Culture: An Experimental Analysis', Journal of Public Economics 94(11-12): 862-9.

Basu, Kaushik. 2011. 'Why, for a Class of Bribes, the Act of Giving a Bribe should be Treated as Legal', Ministry of Finance, Government of India Working Paper No. 1/2011-DEA (March 2011).

Bertrand, Marianne, Simeon Djankov, Rema Hanna, and Sendhil Mullainathan. 2007. 'Obtaining a Driver's License in India: An Experimental Approach to Studying Corruption', Quarterly Journal of Economics November: 1639-76.

Bhavnani, Rikhil. 2009. 'Corruption Among India's Politicians: Insights from Unusual Data', working paper.

Bose, Niloy, Salvatore Capasso, and Antu Panini Murshid. 2008. 'Threshold Effects of Corruption: Theory and Evidence', World Development 36(7): 1173-91.

Bussell, Jennifer. 2012. Corruption and Reform in India: Public Services in the Digital Age. New York and New Delhi: Cambridge University Press.

Chong, Alberto, Ana L. De La O, Dean Karlan, and Leonard Wantchekon. 2012. 'Looking Beyond the Incumbent: The Effects of Exposing Corruption on Electoral Outcomes', Economics Department Working Paper No. 94, Economic Growth Center Discussion Paper No. 1005, Yale University.

Cisar, Ondrej. 2003. 'Strategies for Using Information Technologies for Curbing Public Sector Corruption. The Case of the Czech Republic', Research Report for the Open Society Institute, Budapest.

Collier, David and Robert Adcock. 1999. 'Democracy and Dichotomies: A Pragmatic Approach to Choices and Concepts', Annual Review of Political Science 2: 537-65.

De Figueiredo, Miguel, D. Daniel Hidalgo, and Yuri Kasahara. 2012. 'When Do Voters Punish Corrupt Politicians? Experimental Evidence from Brazil', working paper.

Elkins, Zachary. 1999. 'Gradations of Democracy: Empirical Tests of Alternative Conceptualizations', paper presented at Seminar on Democratization, Stanford Institute on International Studies, Stanford University, 21 January, Stanford, CA.

Ferraz, Claudio and Frederico Finan. 2008. 'Exposing Corrupt Politicians: The Effects of Brazil's Publicly Released Audits on Electoral Outcomes', The Quarterly Journal of Economics May: 703-45.

Fisman, Raymond and Edward Miguel. 2007. 'Corruption, Norms, and Legal Enforcement: Evidence from Diplomatic Parking Tickets', Journal of Political Economy 115(6): 1020-48.

Friedrich, Carl J. 2002 (1972). 'Corruption Concepts in Historical Perspective', in Arnold J. Heidenheimer and Michael Johnston (eds), Political Corruption: Concepts \& Contexts. 3rd edn, New Brunswick, NJ: Transaction Publishers, $15-24$. 
Gardiner, John A. 2002 (1993). 'Defining Corruption', in Arnold J. Heidenheimer and Michael Johnston (eds), Political Corruption: Concepts \& Contexts. 3rd edn, New Brunswick, NJ: Transaction Publishers, 25-40.

Gerring, John and Strom C. Thacker. 2004. 'Political Institutions and Corruption: The Role of Unitarism and Parliamentarism', British Journal of Political Science 34: 295-330.

Glaeser, Edward L. and Raven Saks. 2006. 'Corruption in America', Journal of Public Economics 90: 1053-72.

Golden, Miriam A. and Lucio Picci. 2005. 'Proposal for a New Measure of Corruption, Illustrated with Italian Data', Economics and Politics 17(1): 37-75.

Heywood, Paul. 1997. 'Political Corruption: Problems and Perspectives', Political Studies XLV: 417-35.

Jain, Arvind. 2001. 'Corruption: A Review', Journal of Economic Surveys, 15(1): 71-119.

Kramon, Eric and Daniel N. Posner. 2013. 'Who Benefits from Distributive Politics? How the Outcome One Studies Affects the Answer One Gets', Perspectives on Politics 11(2): 461-74.

Mauro, Paulo. 1995. 'Corruption and Growth', The Quarterly Journal of Economics 110(3): 681-712.

McMillan, John and Pablos Zoido. 2004. 'How to Subvert Democracy: Montesinos in Peru', CDDRL working paper No. 3, Stanford Institute on International Studies, Stanford University.

Montinola, Gabriella R. and Robert W. Jackman. 2002. 'Sources of Corruption: A Cross-Country Study', British Journal of Political Science 32: 147-70.

Nilekani, Nandan. 2013. 'There is a Difference between Wholesale, Retail Corruption', Economic Times, 5 September. Accessed 6 May 2015 at http:// economictimes.indiatimes.com/et-now/daily/there-is-a-difference-betweenwholesale-retail-corruption/videoshow/22345610.cms.

O’Donnell, Guillermo. 1994. 'Delegative Democracy', Journal of Democracy 5(1): 55-69.

O'Donnell, Guillermo and Phillipe C Schmitter. 1986. Transitions from Authoritarian Rule: Tentative Conclusions about Uncertain Transitions. Baltimore, MD: Johns Hopkins University Press.

Olken, Benjamin. 2007. 'Monitoring Corruption: Evidence from a Field Experiment in Indonesia', Journal of Political Economy 115(2): 200-249.

Olken, Benjamin A. and Patrick Barron. 2009. 'The Simple Economics of Extortion: Evidence from Trucking in Aceh', Journal of Political Economy 117(3): 417-52.

Philp, Mark. 2002. 'Conceptualizing Political Corruption', in Arnold J. Heidenheimer and Michael Johnston (eds), Political Corruption: Concepts \& Contexts. 3rd edn, New Brunswick, NJ: Transaction Publishers, 41-58.

Reinikka, Ritva and Jakob Svensson. 2004. 'Local Capture: Evidence from a Central Government Transfer Program in Uganda', The Quarterly Journal of Economics 119(2): 679-705.

Reinikka, Ritva and Jakob Svensson. 2006. 'Using Micro-Surveys to Measure and Explain Corruption', World Development 34(2): 359-70.

Rose-Ackerman, Susan. 1975. 'The Economics of Corruption', Journal of Public Economics 4(2): 187-203.

Rose-Ackerman, Susan. 1978. Corruption: A Study in Political Economy. New York: Academic Press, Inc. 
Rose-Ackerman, Susan. 1999. Corruption and Government: Causes, Consequences, and Reforms. Cambridge: Cambridge University Press.

Rose-Ackerman, Susan. 2002. 'When is Corruption Harmful?' in Arnold J. Heidenheimer and Michael Johnston (eds), Political Corruption: Concepts \& Contexts. 3rd edn, New Brunswick, NJ: Transaction Publishers, 353-72.

Shleifer, Andrei and Robert W. Vishny. 1993. 'Corruption', Quarterly Journal of Economics 108(3): 599-617.

Treisman, Daniel. 2000. 'The Causes of Corruption: A Cross-National Study', Journal of Public Economics 76: 399-457.

Van Rijckeghem, Caroline and Beatrice Weder. 2001. 'Bureaucratic Corruption and the Rate of Temptation: Do Wages in the Civil Service Affect Corruption, and by How Much?' Journal of Development Economics 65: 307-31.

Wei, Shang-Jin. 2000. 'How Taxing is Corruption on International Investors?' The Review of Economics and Statistics 82(1): 1-11. 